\title{
Does government support of a few leading universities have a broader impact on the higher education system? Evaluation of the Russian University Excellence Initiative. ${ }^{1}$
}

\author{
Andrey Lovakova, Anna Panovaa , Ivan Sterligov ${ }^{\mathrm{b}}$, Maria Yudkevich ${ }^{\mathrm{a}}$
}

a Center for Institutional Studies, National Research University Higher School of Economics, Moscow, Russia

b Scientometrics Centre, National Research University Higher School of Economics, Moscow, Russia

Preprint of the earlier version of the published article

Cite:

Lovakov, A., Panova, A., Sterligov, I., Yudkevich, M. (2021). Does government support of a few leading universities have a broader impact on the higher education system? Evaluation of the Russian University Excellence Initiative. Research Evaluation. https://doi.org/10.1093/reseval/rvab006

Contact: Anna Panova, apanova@hse.ru

\begin{abstract}
Many governments attempt to improve the national higher education through competitive support of universities. This approach raises questions about the impact of targeted support for a small number of universities on the entire system - both in educational and research aspects. Using data from Russian University Excellence Initiative (RUEI) that gives as an example, we estimate spillover effects of such focused support and demonstrate that broader impact may indeed exist. In particular, we examine the performance of higher education institutions that were not part of the RUEI in the last five years and were not directly supported by it. We compare the universities' performance in regions both with and without universities from the RUEI. In doing so, we estimate the indirect impact of the RUEI on the higher education sector at the regional level. We show a positive effect on the level of publication activity that has recently become apparent. However, there has been no effect on the share of young faculty, international collaboration in publications, quality of enrollment.
\end{abstract}

Keywords: University Excellence Initiative, spillover effects, state intervention, research productivity, research collaboration, world-class universities, policy evaluation

\footnotetext{
1 The article was prepared within the framework of the HSE University Basic Research Program and funded by the Russian Academic Excellence Project '5-100'.
} 


\section{Introduction}

Common characteristic of national and global academic systems over the past 50 years has been the increasing massification of higher education. Massification contributed to increasing stratification of higher education institutions (Altbach et al., 2017; Clark, 1996, 2002; Hallonsten and Holmberg, 2013). Government regulations become more diversified with policies becoming more targeted. In particular, there has been a shift from a system of uniform financing to selective support of particular universities. One example of targeted government intervention is presented by academic excellence initiatives. Facing increasing globalization, national governments aim to turn national universities into global players on the international market in order to meet growing demand for education and research, and to increase their country's global academic standing (Liu et al., 2016; Kehm, 2013; Shin and Jang, 2013; Altbach, 2003, 2011).

Excellence initiatives themselves lead to greater stratification of national higher education systems (Altbach et al., 2017). Surprisingly little is known about the spillover effects of such programs on education systems in general. A large amount of public funds spent on a small number of universities in order to obtain a certain result inevitably affects other universities and changes the higher education landscape. However, this issue has not actually been investigated. Too much resources allocated to an elite group of universities could be at the expense of national goals (Altbach, 2003). Indeed, while improving the performance of a small, targeted group of universities is usually interpreted as the consequence of increasing efficiency, it might alternatively be explained by the redistribution effect (Teichler, 2008, Kehm, 2013). That is, the supported universities, which receive extra resources, also find themselves in a privileged position and are able to attract intellectual resources from other, less able institutions. The latter institutions, losing more able faculty, may consequently become less efficient, which in turn may lead to lower-quality student intakes, lower research performance, etc. Indeed, some voices claim that the improved performance of selected institutions may be due to local redistribution of talent among students and faculty (Salmi, 2016). The concentration of talented students in a small number of universities could not only be inefficient, but also harmful for equity in higher education (Cook and Frank, 1993; Salmi, 2016); the same is true for faculty. Thus, Sharma (2017) among others argues that in the case of China, there is a problem of local competition for talent, as faculty who are able to publish in good journals are "stolen" by institutions that receive extra-government support. Zong and Zhang (2019) also show that inequality is growing in terms of the academic output between universities from two different Chinese support programs - Project 211 and Project 985. In Japan, as Yonezawa and Shimmi (2016) demonstrate, the gap between top universities and the rest of the system widened after the implementation of an excellence initiative. 
Hence, the overall effect of a university excellence initiative may be less evident than it seems from a direct comparison of the universities supported by the initiative, and those with comparable characteristics which are not part of the initiative. On the other hand, government regulations imposed on universities may affect both leading institutions and the rest of the system. Other potential spillovers (both positive and negative) should also be taken into consideration when the effect of an excellence initiative is examined. Relationships between universities at a regional level are important for developing policies (Seeber et al., 2012). The empirical evidence of spillover effects is limited, and our study fills an important gap in the literature.

Academic excellence initiatives have been implemented in several countries across the world with Russia being among them. The Russian University Excellence Initiative (also known as the 5100 Project) was launched in 2013 and assumed a targeted support of selected universities in the period 2013-2020. Recent research show that since its start, there has been a significant growth in research output of participating institutions, both in quantitative and qualitative terms (Turko et al., 2016; Poldin et al., 2017, Guskov et al., 2018; Matveeva et al., 2019), and a significant improvement in the positions of Russian universities in international university rankings at both institutional and subject levels (QS World University Rankings 2019: Russia, 2020). In broader context, these years changed the role and place of research in higher education sector at the country level: general university research performance (both measured in the number of publications in international peerreviewed journals and in number of authors from higher education institutions) began to grow sharply (Kosyakov and Guskov, 2019; Guskov et al., 2017); collaboration between universities and institutes of Russian Academy of Sciences has intensified, the proportion of publications in Scopus affiliated with higher education institutions increased from 32\% to 58\% during 1998-2017 (Kosyakov and Guskov, 2019). Various government policies and measures, including RUEI, contributed to a change in the university's role in knowledge production which traditionally was suppressed by the non-teaching academic sector.

We investigate how the university sector responds to the intervention, and we focus on spillover effects at a regional level. Our basic assumption is that if a university from the RUEI can affect another university, the effect should be to large extent limited to the same city or region. This assumption is plausible, since we are dealing with an oligopolistic regional academic market. Leading universities are important for the academic sector in their home regions. Large financial injections into these selected universities, and greater attention on them, could lead to dramatic shifts in regional academic markets.

In order to estimate spillover effects, we examine the relative performance of higher education institutions that have not been part of the RUEI in the last five years and were not directly supported by this initiative in two types of regions: those that contain RUEI universities, and those 
that do not. Our analysis covers the period from 2012 to 2017. This allows us to study whether the performance of universities located in close proximity to RUEI universities has significantly changed relative to other universities since the launch of the initiative.

Our paper contributes to the higher education and research literature by exploring mechanisms through which excellence initiatives may affect not only the target group itself but the rest of the system as a whole. Indeed, we argue that changing the priorities of government policy and an attempt to boost research and competition in several selected universities could affect other universities in the country as well. This idea goes in line with a modern public economics approach that both direct and indirect consequences of government interventions may and should be studied. Our results give new insights into the influence of one such intervention, the academic excellence initiative, at the regional academic market. We not only see a substantial difference between universities from RUEI and other universities but also find a spillover effect from the RUEI manifesting, among other things, in an increased number of papers written in collaboration with neighboring universities. A small positive effect on the level of publication activity has just started to become apparent.

While focusing on the data from one country, our paper suggests the framework that might be used to the study of direct and indirect effects of excellence initiatives implemented in other systems with high heterogeneity across regions. We focus mostly on parameters related to research performance of institutions and show that this performance is highly sensitive to external policies and exogenous shocks that the university system faces.

\section{The Russian University Excellence Initiative in the context of other excellence initiatives}

There have been more than 30 initiatives in the last decade (Salmi, 2016). As Altbach and Salmi (2011) stated, it is important to take into account the environment of world-class universities. Universities do not exist in a vacuum, they interact with each other and with other institutions involved in research (Seeber et al., 2012; Altbach and Salmi, 2011). All that affects both the implementation and results of these initiatives. Such programs are usually launched and funded by a state and administered by a state body. Programs mostly target public universities, with a few exceptions such as Japan, Taiwan, and Korea. Research excellence is a core issue of most programs, and as a result success is often measured by promotion in international rankings (Salmi, 2016).

It is very difficult to assess the impact of excellence initiatives, since it takes time for such programs to start yielding sustained results, and it is also difficult to prove that any changes occurred because of the programs (Salmi, 2016). Many scholars ask about the effect of such programs on the national system. Usually direct effects only are assessed (Matveeva and Ferligoj, 2020; Zong and 
Zhang, 2019; Matveeva et al., 2019; Menter et. al., 2018; Hou et al., 2012; Möller et al., 2016; Cuntz, 2016). For example, one may study whether national universities have progressed in international rankings or have become more visible on the global academic market (Benito et al., 2019; Salmi, 2016; Möller et al., 2016). In Russian case, such an effect really exists (Matveeva et al., 2019; Poldin et al., 2017; Turko et al., 2016). However, it is impossible to discard the questions of the academic community about what is happening to those higher education institutions outside of the RUEI. There is a lack of empirical studies about government intervention in the public sector, and in particular about the spillover effects of excellence initiatives. There are, however, researchers who refer to possible consequences (Kehm, 2013; Gaehtgens, 2015; Cremonini et at., 2013; Shin and Jang, 2012).

Experts claim that potential effects on national systems may be substantial (and mixed) (Kehm, 2013; Gaehtgens, 2015). The focus on research and the global market leads to the fact that, as a result, only certain types of universities - those that can potentially advance in the global market - may enter such programs. These would include large universities, and universities where STEM disciplines play an important role (Salmi, 2016). Such a bias can be seen in various countries (Salmi, 2016). This means that universities that are small, teaching-oriented, or specialize in social sciences and humanities may suffer (Gaehtgens, 2015; Kehm, 2013; Cremonini et al., 2013), since they do not receive special attention or government support. In addition, there is a reorientation in public policy toward research excellence, which might affect other universities (Koenig et al., 2017) and also a reorientation from supporting specific researchers to supporting institutions (Gaehtgens, 2015). Cremonini et al. (2013) note that excellence initiatives can lead to segregation; instead of becoming drivers for the entire national system, world-class universities can provoke a redistribution of resources in their favor, in order to maintain their position in the global market. Cremonini et al. (2013) conclude that world-class universities alone do not lead to improvement in the entire university sector, as can be seen in France. One effect that has been evaluated at a regional level is the impact of excellence initiatives on changing the structure of university funding. In Germany, regions with large universities have benefited from the implementation of an excellence initiative. The amount of merit-based third party research funding for universities in those regions rose significantly compared with regions where small universities are more prevalent (Koenig, 2017).

These kinds of programs increase the mobility of resources between institutions as well as their interdependence, so one might expect some spillover effects. Such effects exist in other educational markets. For instance, scholars analyzed the effect on the school educational market from the implementation of vouchers in the USA (Epple and Romano, 1998), from the appearance of charter schools in the USA (Ferreyra and Kosenok, 2018; Cordes, 2018) and independent schools in Sweden (Wondratschek et al., 2013; Edmark, 2019). 
The aim of the Russian University Excellence Initiative is to have several Russian universities in the top world rankings, in order to improve the global visibility and competitiveness of the Russian higher education system. In other words, the initiative aims to create world-class universities. So in the principal goal the RUEI is similar to other programs.

Russian higher education system has some features that distinguish it from other countries. While both private and public universities are represented in the academic market, about 90 percent of students study at public universities. Russian private universities are not involved in research and focus on teaching only. Public universities vary in the size of the student body and of the faculty body (from several dozen to several thousand people). The average size of an RUEI university is 17,600 students and around 1,300 faculty. Russia has 85 regions, which vary significantly in the quality of education and economic development. While there are regional ministries of education, all public universities are under direct supervision of the federal government and are funded centrally. The geographical distribution of universities across the country is uneven but in most regions there are oligopolistic local academic markets (with six public universities on average in one region in 2018). All of these markets differ in the average scores obtained by prospective students in the unified state examinations (USE), with a range of more than 20 points out of 100 in mathematics and Russian language. Higher education institutions are mainly located in regional capitals. The diversity of regions' economic and educational development creates a variety of market prospects for young people. This leads to a migration of young people in search of better higher education to a limited number of regions (Kashnitskiy et al., 2016). Regions also vary in size and have their own infrastructure; sometimes, in order to travel to a neighboring region, one has to get a flight with a connection through a more distant region. Thus, there are certain economic and educational characteristics that distinguish Russia from other countries and make our analysis most interesting at the regional level.

The RUEI was launched in 2013, with the aim of supporting a group of leading universities with a strong international academic reputation, and to improve the global visibility of Russian universities. The RUEI is a government program with the stated goal of seeing at least five national universities placed in the top 100 in global university rankings by 2020 . The government assumed that this initiative will also boost the performance of the public higher education sector as a whole (Salmi, 2016). The RUEI was launched as an open competition, targeted at public higher education institutions. Selection for the initiative was based on each university's development strategy, demonstrating how it would reach the goal, and its current academic performance. The main focus was research performance, collaboration, and integration into the global market. Universities would need to develop an infrastructure enabling them to attract the best talent among academic, students, and managers. Today, the RUEI includes 21 universities in 13 regions. Figure 1 shows the 
distribution of these regions, with RUEI universities across Russia. There were two waves of selection: 2013, when 15 universities were selected, and 2015 when a further six were chosen. Most of the selected universities were large. Annual funds are provided on a competitive basis, with permanent monitoring of short-term achievements. Since 2013, the government has spent 80 billion rubles on financing universities in this program ( $\$ 3.2$ billion dollars in purchasing power parity). In 2016 this support averaged about 9\% of the university budget. There are a limited number of key indicators that are monitored and used to measure the achievements including those that measure research and human capital quality: the number of peer-reviewed publications and citations per capita, the share of international students, the quality of student intakes, and money for R\&D that universities attract.

\section{Analytical framework}

Salmi (2016) suggests that there are "three complementary sets of factors at play in top research universities: (a) a high concentration of talent (faculty and students); (b) abundant resources to offer a rich learning environment and to conduct advanced research; and (c) favorable governance features that encourage leadership, strategic vision, innovation, and flexibility and that enable institutions to make decisions and manage resources without being encumbered by bureaucracy".

While the third set of factors mostly refer to the inner structure of the institution, and are not much affected by the behavior and characteristics of other institutions, the first two are much more strategic and imply externalities between different institutions. The second set of factors influences to a large extent the composition of the first: the ability of universities to attract top talents depends on all its resources, not just its financial strength.

In our paper, we mostly concentrate on the first factor - a high concentration of talent. National excellence initiatives reshape mobility of talents among European countries (Cuntz, 2016), in large counties we could expect reshaping at a regional level. Since leading Russian universities are not yet active players as employers at the global academic market (Kuskova and Yudkevich, 2016), and the primary source of human resources for them is the local academic market, one might expect that the increased ability of some selected universities to attract the best faculty would negatively affect other Russian institutions. The same is true of students.

In both cases (faculty and students), supply and demand work in a way that means the best talents should be concentrated in the best universities. Indeed, faculty may be attracted both by better salary prospects as well as a stronger academic environment. The prestige of a university, its intellectual environment, quality of colleagues, potential for intellectual exchange, and the possibility to work with high-quality students can all play an important role in faculties' intentions to change jobs (Zhou and Volkwein, 2004; Brown, 1967; McGee and Ford, 1987). A university's 
entry into an excellence initiative can be a signal of its high-quality academic environment. If we consider students, then the university's reputation quality and financial support play important roles in choosing a university (Bhardwa, 2017; Ming and Kee, 2010, Cook and Frank, 1993). Students may be interested in studying in RUEI universities, since participation in the initiative is a signal of quality. Thus, prospective students of these universities may expect positive effects from the strong student and faculty bodies and better international prospects. Simultaneously, one of the key indicators of university performance in the RUEI is the quality of student intake (measured by the minimum entry qualification for the educational program). For this reason, universities have extra incentives to aim for strong students. Research-oriented faculty are interested in good students as well. One might expect that high-ability students and faculty would migrate toward RUEI universities, especially when such universities exist in their home region. Thus, the Matthew effect can work when a university with a higher status attracts more and more high-quality resources.

Concurrently the selected university can positively influence the academic environment of its home region, making the region as a whole more attractive for faculty and students. Each university boosts the economic development of its home region (Astebro and Bazzazian, 2011; Koenig et al., 2017, Drucker and Goldstein, 2007), thereby making it attractive for talent. The university may be a signal that the region has a high-quality academic environment. Talented students, choosing this region, can apply to several universities; some will enroll in the RUEI university, others will go elsewhere. The dissemination of academic standards can occur both at the organization level and at the level of individual faculty. Selected universities can disseminate their standards through methods such as holding conferences and inviting world-famous professors, and holding refresher courses. The regional ministry may consider the selected universities as a benchmark and impose new requirements on the other universities; one might then talk about coercive isomorphism (DiMaggio and Powell, 1983; Croucher and Woelert, 2016). Mimetic isomorphism is also possible, when universities themselves are geared to, and implement, the best practices of the universities in the excellence initiative. Normative isomorphism is also possible, when these practices become the norm as a result of professional pressure. In turn, faculty at the selected university could, in order to achieve key publication performance indicators, collaborate with faculty from other universities.

Thus, one university in a region that succeeds in meeting the selection process for the excellence initiative can lead to different effects: either the redistribution of resources, or an improvement in the quality of resources. In order to assess the effect on the universities that are not part of the excellence initiative, we compare the quality of resources in universities in two types of regions: those that have RUEI universities, and those that do not. We examine the quality of incoming students, and also the quality of faculty by evaluating various aspects of their publication activity. 


\section{Data}

Our database contains data from: Monitoring of the Effectiveness of Educational Institutions (collected annually by the Ministry of Education and Science on the basis of universities' mandatory self-reporting); the Russian Index of Science Citation (RISC), a Russian national citation index, covering almost all Russian scientific journals (for the overview see Moskaleva et al. 2018); and the Web of Science (WoS) database. Our database covers the period before and after the start of the Russian University Excellence Initiative, allowing us to study the effect of policy intervention.

We use different variables to measure university performance and its dynamics, focusing mostly on indicators related to the quality of human capital (both students and faculty) and research performance. While there are many other potential indicators of university performance, we focus on these two groups as key ones. Indeed, being a world-class university is associated with topquality research and best talents attracted from over the world (Salmi, 2016; Tayeb, 2016). Substantial changes take time. However, the design of the program requires universities to report annually and to seek mechanisms to demonstrate improvements every reporting period. Yearly assessments of key performance indicators lead to quick and marked changes in financial support for program participants. So, it pushes universities toward strategies that give immediate returns. These include attracting productive faculty on a part-time basis (including those from nearby institutions and international faculty), supporting international collaborations (including megascience projects) (Powell et al., 2017), focusing on publications that allow faster publication cycle. At the same time, one should not expect immediate increase in the share of young faculty, which are important for sustainable development but require long-term investment and support.

To measure the quality of human capital (both students and faculty) and research output of the universities we use a number indicators related to the quality of student intake, faculty structure, and quantitative and qualitative characteristics of scholarly output.

Quality of students' human capital was measured by the average of the Unified State Exam (USE) scores (which all applicants pass in order to enter a university) among undergraduate students accepted onto state-funded places. Faculty structure was measured by (1) the percentage of young faculty, (2) the percentage of international faculty (those who have foreign citizenship). The young academics includes those up to age of 30 without a degree, Candidates of Science (the Russian equivalent of a $\mathrm{PhD}$ ) up to the age of 35 , and Doctors of Science (a second-level academic degree in Russia, analogous to a German Habilitation) up to age of 40. These three indicators were extracted from the Monitoring database for each university for 2012-2017.

Quantitative and qualitative characteristics of research output was measured via publication counts in different collections of journals to reflect their vastly varied international standing: (1) the RISC Core, i.e., journals indexed in the WoS Core Collection, Scopus, or selected for Russian 
Science Citation Index on the WoS platform (Moskaleva et al., 2018); (2) the WoS Core Collection (excluding journals indexed in ESCI); (3) WoS Core Collection journals from Q1 by journal impact factor. This set of publication indicators allows to measure the universities' output with different levels of quality and visibility (the lowest is in RISC, the highest is in journals from Q1 by journal impact factor). While the first set contains 1102 Russian journals, only 162 of them are in the second set, and only a handful in the first JIF quartile (6 in 2016, 1 in 2019, while 130 are in the fourth quartile). Of the 38180 articles and reviews with Russian affiliation in WoS Core Collection (excluding ESCI) in 2016, 24\% was published in Q1 journals, but they attracted 63\% of total citations. While more than $70 \%$ of Russia's Q1 papers in this year had additional international affiliations, for Q4 journals this share plummets to $11 \%$ (authors' calculations based on InCites $\backslash$ WoS data).

RUEI institutions are mostly interested in Q1 papers because they are more cited and bring more academic reputation, which is precisely what is needed to improve positions in THE, QS and ARWU university rankings used by the initiative (see Moed, 2017 for a critical review of their methodology and the use of bibliometric indicators).

To measure the universities' collaboration patterns we use two specific indicators: (1) the number of publications in the WoS Core Collection (excluding journals indexed in ESCI) in international collaboration (having several authors and affiliated with two or more countries), (2) the number of publications in WoS Core Collection in collaboration with RUEI universities.

We excluded several regions and institutions from our sample. Moscow and St. Petersburg were excluded since these regions are significantly more economically developed than others, and during the period under review the academic market in these regions underwent significant changes. Kaliningrad and Crimea were excluded since it is difficult to reach other regions from either of them. We also excluded those regions with institutions that joined the RUEI only during the second wave of selection in 2015, and those that differed significantly from the treatment group in terms of economic and educational quality before 2013 (notably, the regions below the 5th percentile for average USE scores in Russian and mathematics, or in the region's socio-economic rating). Furthermore, several types of higher education institutions were excluded: private higher education institutions (since they cover a small percentage of the student body and focus mainly on teaching), branches of institutions (since they are not autonomous and are highly dependent on the head university) and sport and art institutions (since they are teaching oriented and their teaching methods are significantly different). The final sample included 399 universities.

\section{Methodology}

We used the Differences-in-Differences (DID) approach to test the effect of the RUEI on institutions that are not part of the initiative. This method was used to assess the direct effects in the 
university sector in different countries (Fu et al., 2018; Matveeva et al., 2019; Zong and Zhang, 2019). For the treatment group, we considered institutions outside the RUEI from a city that has at least one institution included in the initiative. For the control group, we took institutions outside the RUEI from a capital of regions with institutions not included in the initiative. Figure 2 shows the distribution of regions and cities with universities from the treatment and control groups across Russia. The number of universities in each group is presented in Table 1. Such a choice is explained by the fact that potential spillovers from strong to weak institutions should be stronger within a region, not between regions. Since our data are observations of the performance indicators of the same universities for different years, the observations are not independent. To take this into account, we use a linear mixed-effects model via REML with random intercepts for universities for all indicators using the lme4 package in R (Bates et al., 2015).

We used two specifications. In the first specification, we divided observations into two periods: 2012-2013 and after 2013. Since the RUEI was introduced in 2012, 2013 was the first full year following the intervention. However, to increase the number of observations in the period before the intervention, we attributed the 2013 observation to the pre-intervention period. Since the values of UPIs that we analyzed cannot change immediately, we did not expect the effect of the RUEI to appear on the following year's data.

\section{Specification 1}

$Y_{i t}=\beta_{0}+\beta_{1}$ After_initiative $_{i t}+\beta_{2}$ Treat $_{i}+\beta_{3}$ After_initiative $_{i t} \cdot$ Treat $_{i}+\beta_{4}$ SN $_{i}+u_{i}+e_{i t}$

$Y_{i t}-$ university performance indicators.

After_initiative $_{i t}$ - dummy variables for the time period after the RUEI was introduced, coded 1 if the observation was in the time period after 2013 and 0 if the observation was in the period 2012 2013.

Treat $_{i}$ - dummy variable for treatment group, coded 1 if the observation refers to the university from the treatment group, and 0 if it refers to the university from the control group.

After_initiative $_{i t} \cdot$ Treat $_{i}$ - dummy variable for the interaction; the coefficient for this variable captured the treatment effects of the RUEI.

$S N_{i}-$ dummy variables for a strong neighboring region, coded 1 if the university was from a region that had a strong neighboring region (Moscow, St Petersburg, or regions with universities from the RUEI) and 0 if there was no strong region in the neighborhood.

$u_{i}$ - university-specific random effect. 


\section{Specification 2}

The second specification is similar to the first, but instead of the dummy variable dividing observations into periods before and after the intervention, we included a set of dummy variables for a specific year (2012 being the reference year). This specification allows us to identify the time when any effects of the intervention began to appear.

$Y_{i t}=\beta_{0}+\beta_{1}$ Time $_{i t}+\beta_{2}$ Treat $_{i}+\beta_{3}$ Time $_{i t} \cdot$ Treat $_{i}+\beta_{4} S N_{i}+u_{i}+e_{i t}$

$Y_{i t}$ - university performance indicators.

Time $_{i t}$ - dummy variables for years (2012 is the reference).

Treat $_{i}-$ dummy variable for treatment group, coded 1 if the observation refers to a university from the treatment group and 0 if it refers to a university from the control group.

Time $_{i t} \cdot$ Treat $_{i}-$ dummy variables for the interaction; coefficients for these variables capture the treatment effects of the RUEI in a specific year

$S N_{i}$ - dummy variables for strong neighboring region (Moscow, St Petersburg, or regions with universities from the RUEI

$u_{i}$ - university-specific random effect.

Table 1. Number of universities by groups

Total number of universities 399

In the RUEI

Outside the RUEI

Treatment (from a city where there is at least one RUEI university) 54

$\begin{array}{ll}\text { Control (from a capital of a region where there are no RUEI universities) } & 167\end{array}$

Other (from excluded regions and cities which are non region capitals)

163

\section{Results}

\section{University performance indicators inside and outside RUEI}

Based on the analysis of the dynamics of the UPIs during the analyzed period in a group of RUEI universities and among non-RUEI universities (Figures 3 and 4), we can draw several conclusions. The first explicit conclusion that can be made is that universities included in the initiative are significantly ahead of other universities in all indicators, starting from the period before the introduction of the program. This result is not surprising, because the RUEI includes stronger and more successful universities, including those on the UPIs we are considering. In addition to the presence of a gap between universities in and outside RUEI, we also observe this gap growing in some indicators.

The trends in the USE score among undergraduate students accepted for state-funded places into universities inside and outside RUEI are generally the same. There are several spikes (2013, $2015,2017)$ and falls $(2014,2016)$ in the average USE score. However, they are observed both at 
universities within and outside RUEI. In the case of the share of young academics and foreign academics, the picture is different, the gap becomes wider. The share of young academics at RUEI universities has remained around $25 \%$ throughout the years, but there has been a slight decline in 2016 and 2017. While in non-RUEI universities, there is a steady decline in the proportion of young academics (from $20 \%$ to $15 \%$ on average). The share of foreign academics is quite low (less than $2 \%$ on average) at Russian universities both inside and outside RUEI. However, RUEI universities have seen an increase in the share of foreign academics throughout the analyzed period. From 2012 to 2017, the share of foreign academics at these universities more than doubled on average. At nonRUEI universities, the share of foreign academics remained less than $1 \%$ throughout the analyzed period. In terms of the quality of the human capital of faculty, the gap between universities is increasing. This affects the research output. As a result the similar tendency is observed for publication indicators (Figure 4). For all of them (number of publications in RISC, WoS, Q1, and publications in international collaboration), substantial growth is observed at RUEI universities inside (by 2 or more times). Concurrently, there is almost no growth in these publication rates at non-RUEI universities.

Comparison of universities allows us to argue that after implementation of RUEI vertical differentiation increased. Results of comparison show that the gap between the leading universities and the rest of the universities in the country, which was already before the start of the excellence initiative, has become even wider. However, it is difficult to say to what extent this is related to RUEI. It is possible that the development trends of leading universities and other universities in the country would be different even in the absence of superiority initiative. Analysis at the regional level will reveal the possible impact of RUEI universities on the neighboring universities. 

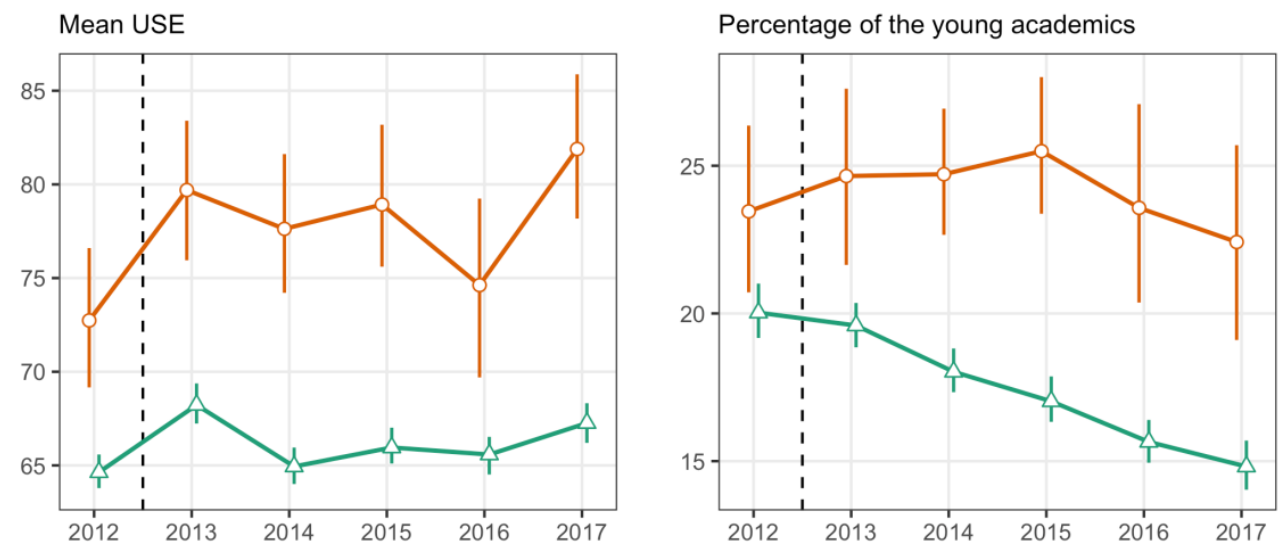

Percentage of the foreign academics

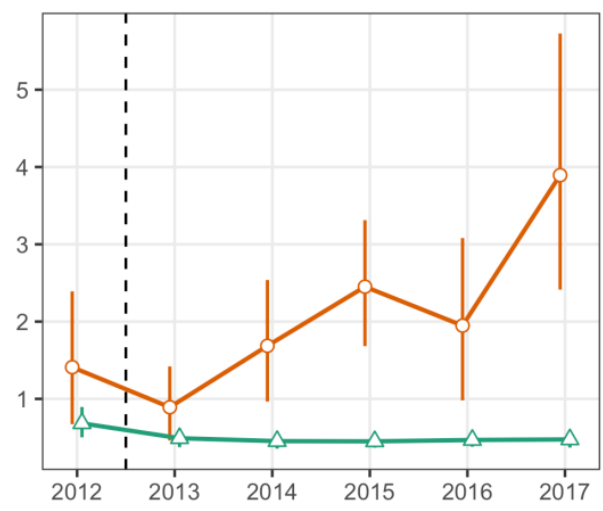

- - Russian University Excellence Initiative

$\triangle$ Outside Russian University Excellence Initiative

Figure 3. Means and 95\% confidence intervals for student and faculty indicators inside and outside RUEI. 

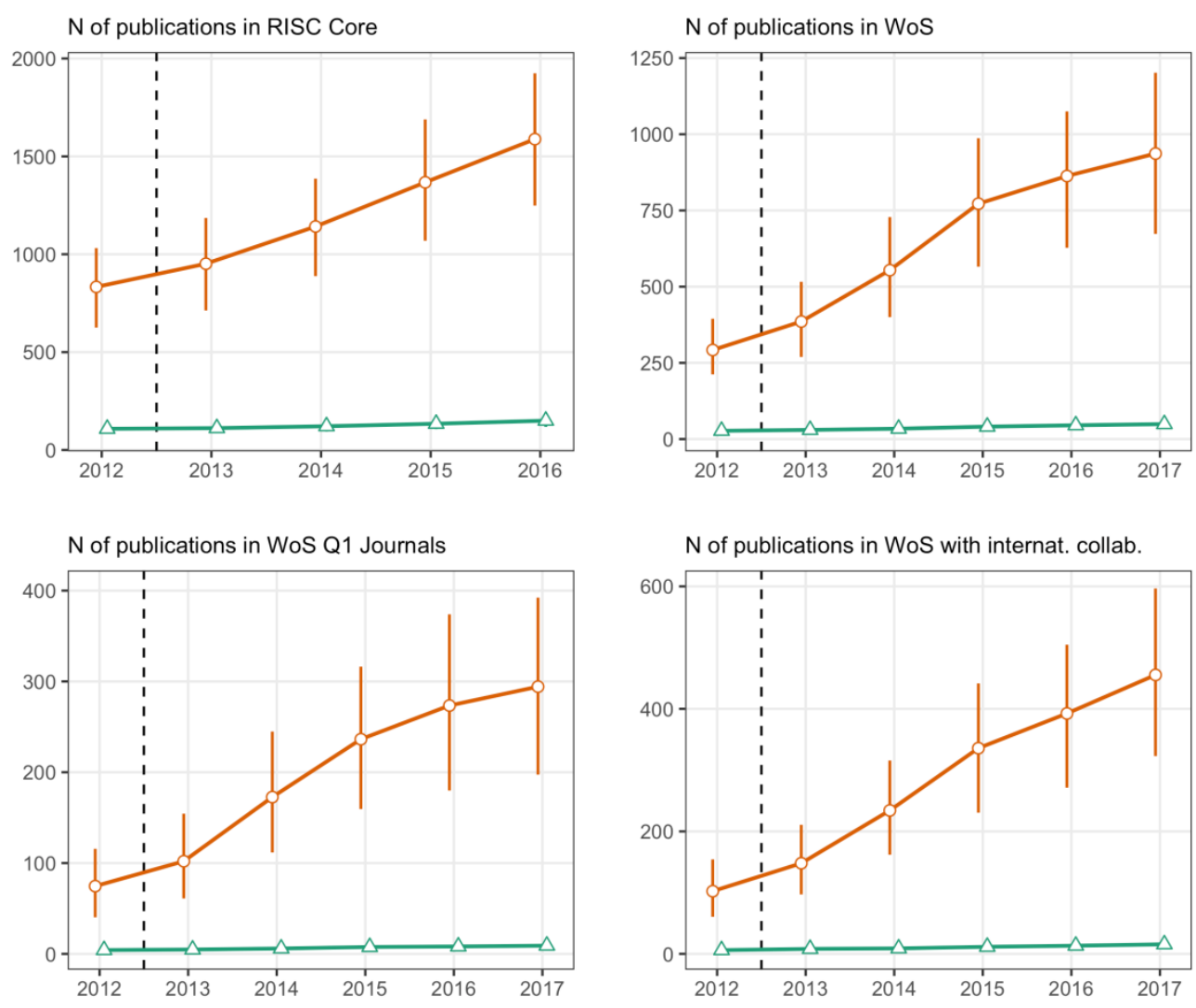

$$
\begin{aligned}
& -\infty \text { Russian University Excellence Initiative } \\
& -\triangle \text { Outside Russian University Excellence Initiative }
\end{aligned}
$$

Figure 4. Means and 95\% confidence intervals for number of publications inside and outside RUEI.

\section{Proximity effects: do neighbors from RUEI matter?}

We tested the effect of having RUEI members on non-RUEI university performance by comparing UPIs of universities neighboring RUEI universities, i.e. located in the same cities as RUEI universities (treatment group), with UPIs of universities not neighboring RUEI universities, i.e. located in the capitals of regions where there are no universities included in the RUEI (control group). In 2012, the average USE scores were identical in the treatment and the control groups (Figure 5). Since 2013, the average USE scores in the treatment group are much higher than in the control group. However, both in the treatment group and in the control group the confidence intervals for the mean values are quite wide, which indicates a large dispersion in the average USE scores between universities within both groups. The share of young academics is the same in both groups and decreases over time (from $22 \%$ to $15 \%$ ). The percentage of foreign academics is also the same in both groups before the start of RUEI and remains approximately at the same low level (with small fluctuations) throughout the analyzed period. 
In 2012, i.e. before the RUEI was introduced, universities from the treatment and control groups had, on average, the same number of publications in the RSCI Core, in WoS, and in WoS Q1 journals. The number of publications in all these three samples of journals increased over time. At the same time, in the treatment group, the number of publications in WoS and in WoS Q1 journals (after 2014) is growing on average somewhat faster than in the control group (Figure 6). However, the confidence intervals for the means are also wide, which indicates a large dispersion of indicators between universities in both groups. A similar picture is observed for the number of publications in international collaboration. The number of publications in international collaboration is also the same in both groups before introducing the RUEI and grows throughout the analyzed period with the same rate in both groups.
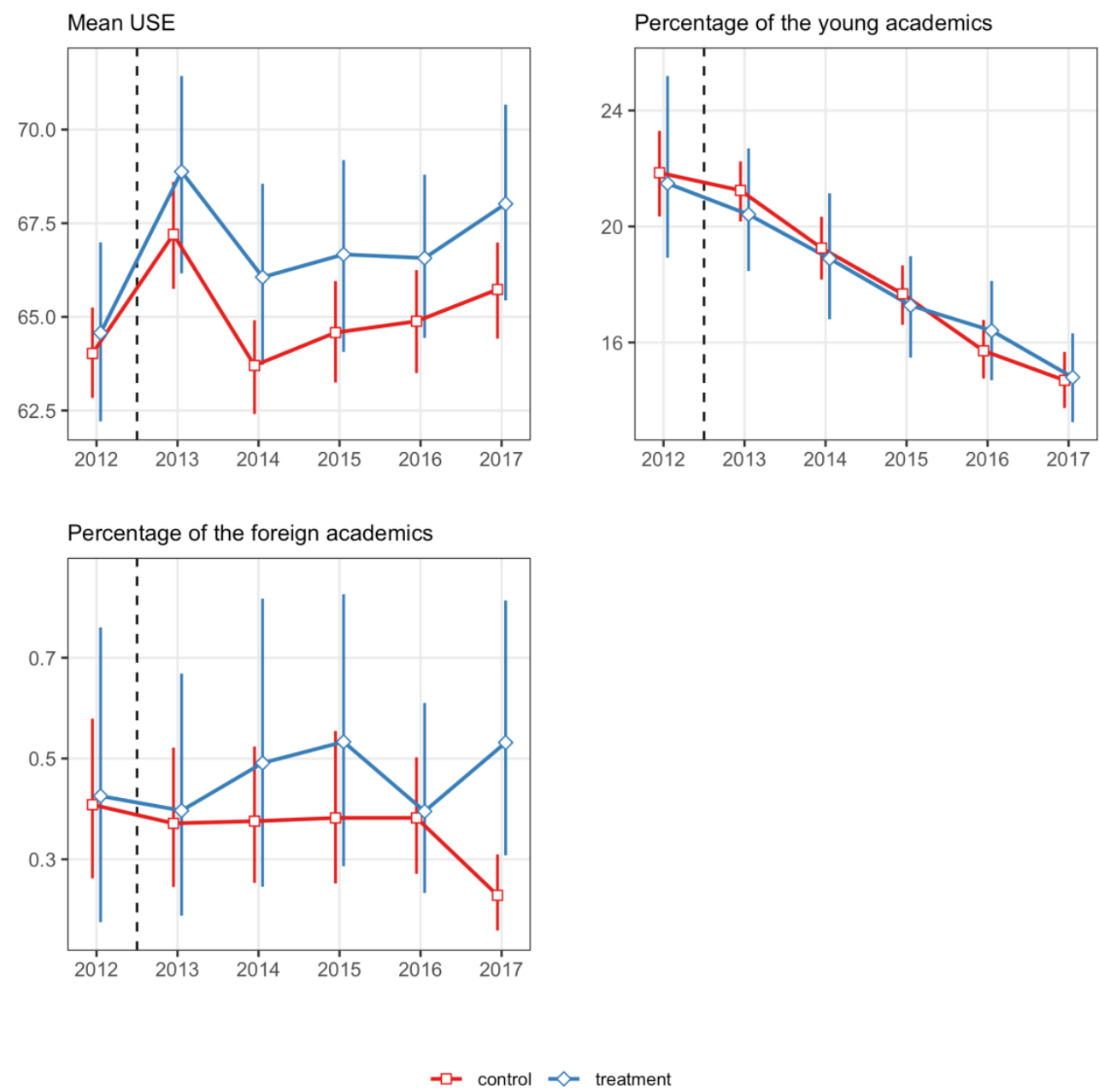

Figure 5. Means and 95\% confidence intervals for student and faculty indicators 

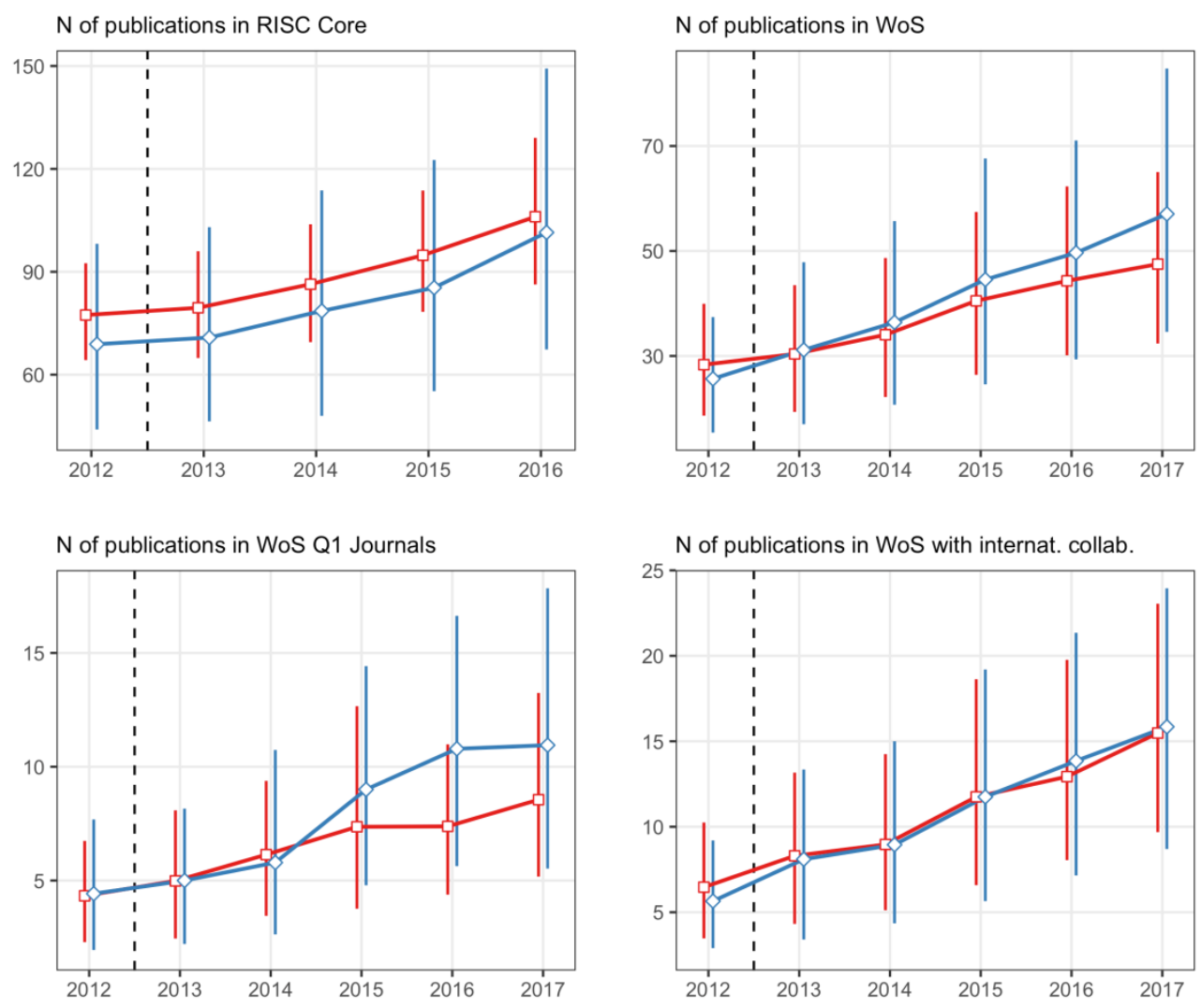

Figure 6. Means and 95\% confidence intervals for number of publications in treatment and control groups.

Next, we ran a series of regressions for our set of UPIs. Descriptive statistics for the UPIs, for both the whole sample and the treatment and control groups, are presented in Table 2. The results of the regression models for the first specification show that the DID estimator is statistically significant only for two indicators (Table 3): number of publications in WoS at the level of 5\% ( $b=6.28, p=.044$, model 1-5) and number of publications in WoS Q1 journals at the level of $10 \%$ ( $b=1.72, p=.064$, model 1-6). The treatment group outperforms the control group in terms of growth in the number of publications in WoS and in WoS Q1 journals. The difference between the groups in other indicators is not confirmed in the regression analysis: average USE $(b=0.93, p=.171$, model $1-1)$, percentage of young academics $(b=0.61, p=.422$, model 1-2), percentage of foreign academics ( $b=0.12, p=.146$, model 1-3), number of publication in RISC Core $(b=1.31, p=.728$, model 1-4), number of publication in $\mathrm{WoS}$ in international collaboration $(b=0.83, p=.574$, model 1-7).

The regression models for the second specification generally replicate the results of those for the first (Table 4). The DID estimators are statistically significant for the same indicator of number of publications in WoS. However, the treatment effect began to appear only in 2016-2017. The DID estimator in the model for the number of publications in WoS became statistically significant at the 
level of $10 \%$ only in $2016(b=8.03, p=.093)$ and at the level of 5\% in $2017(b=12.24, p=.010$, model 2-5). Again, the treatment group outperforms the control group in terms of growth in the number of publications in WoS starting with 2016. However, the DID estimator for individual years is also statistically significant in other UPIs' models. The treatment group outperforms the control group in terms of growth in the percentage of foreign academics in $2017(b=0.28, p=.041$, model 2-3) and in number of publication in WoS Q1 journals in $2016(b=3.32, p=.024$, model 2-6). Again, the effect of the RUEI only began to manifest four-five years after its introduction. However, in all cases of statistically significant effects, the $p$-value is only slightly below the threshold, thus, one cannot say that there is a robust and stable RUEI effect on neighboring universities.

Figure 7 shows that the number of WoS articles written in collaboration with RUEI universities increases with time, in both groups. However, it grows faster in the treatment group. Regression analysis confirms this conclusion. In the first regression model specification, the DID estimator is statistically significant $(b=7.92, p<.001$, model 1-8), i.e. the number of WoS publications in collaboration with RUEI universities grows faster in the treatment group than in the control group after the introduction of the initiative (Table 5). In the second specification model, the DID estimator begins to be statistically significant in 2014 and continues to be significant for all subsequent years (model 2-8), while the value of the coefficient for the DID estimator grows over the years (6.37 in 2014, 8.93 in 2015, 8.80 in 2016, and 11.53 in 2017). Thus, the difference in growth in the number of WoS articles in collaboration with RUEI universities between treatment and control groups arose in 2014 and remained in subsequent years, increasing in size.

Table 2. Descriptive statistics of university performance indicators

\begin{tabular}{|c|c|c|c|c|c|c|c|c|c|}
\hline \multirow[t]{2}{*}{ Variable } & \multicolumn{3}{|c|}{ Whole sample } & \multicolumn{3}{|c|}{ Treatment group } & \multicolumn{3}{|c|}{ Control group } \\
\hline & Mean & $S D$ & $N$ & Mean & $S D$ & $N$ & Mean & $S D$ & $N$ \\
\hline Mean USE & 65.45 & 8.94 & 1323 & 66.79 & 9.45 & 323 & 65.02 & 8.72 & 1000 \\
\hline$\%$ of young academics & 18.36 & 7.98 & 1326 & 18.21 & 8.58 & 324 & 18.41 & 7.78 & 1002 \\
\hline$\%$ of foreign academics & 0.38 & 0.9 & 1324 & 0.46 & 0.99 & 322 & 0.36 & 0.87 & 1002 \\
\hline No. of publ. in RISC Core & 86.94 & 117.98 & 1095 & 81.03 & 121.49 & 265 & 88.83 & 116.85 & 830 \\
\hline No. of publ. in WoS & 38.25 & 58.12 & 528 & 40.74 & 44.42 & 120 & 37.51 & 61.6 & 408 \\
\hline $\begin{array}{l}\text { No. of publ. in WoS Q1 } \\
\text { journals }\end{array}$ & 6.75 & 12.44 & 462 & 7.66 & 10.44 & 114 & 6.46 & 13.03 & 348 \\
\hline $\begin{array}{l}\text { No. of publ. in WoS in } \\
\text { international collaboration }\end{array}$ & 10.66 & 19.6 & 480 & 10.69 & 14.25 & 120 & 10.65 & 21.1 & 360 \\
\hline $\begin{array}{l}\text { No. of publ. in } \\
\text { collaboration with RUEI } \\
\text { universities }\end{array}$ & 6.41 & 12.2 & 444 & 13.78 & 19.7 & 120 & 3.68 & 5.8 & 324 \\
\hline
\end{tabular}

Note. Each observation is for a university year. 
Table 3. Regression models. Specification 1.

\begin{tabular}{|c|c|c|c|c|c|c|c|}
\hline & Model 1-1 & Model 1-2 & Model 1-3 & Model 1-4 & Model 1-5 & Model 1-6 & Model 1-7 \\
\hline & Mean USE & $\begin{array}{c}\% \text { of } \\
\text { young } \\
\text { academics }\end{array}$ & $\begin{array}{c}\% \text { of } \\
\text { foreign } \\
\text { academics }\end{array}$ & $\begin{array}{l}\text { No. of publ. } \\
\text { in RISC } \\
\text { Core }\end{array}$ & $\begin{array}{c}\text { No. of publ. in } \\
\text { WoS }\end{array}$ & $\begin{array}{c}\text { No. of publ. } \\
\text { in WoS Q1 } \\
\text { journals }\end{array}$ & $\begin{array}{l}\text { No. of publ. in } \\
\text { WoS in } \\
\text { international } \\
\text { collaboration }\end{array}$ \\
\hline (Intercept) & $\begin{array}{c}64.38^{* * *} \\
(0.91)\end{array}$ & $\begin{array}{c}21.82^{* * * *} \\
(0.71)\end{array}$ & $\begin{array}{l}0.47^{* * * *} \\
(0.09)\end{array}$ & $\begin{array}{l}80.04^{* * *} \\
(13.40)\end{array}$ & $\begin{array}{l}31.03^{* *} \\
(10.10)\end{array}$ & $\begin{array}{l}5.47^{*} \\
(2.40)\end{array}$ & $\begin{array}{l}9.10^{*} \\
(3.56)\end{array}$ \\
\hline After initiative & $\begin{array}{l}-0.88^{* *} \\
(0.33)\end{array}$ & $\begin{array}{c}-4.71^{* * *} \\
(0.37)\end{array}$ & $\begin{array}{l}-0.05 \\
(0.04)\end{array}$ & $\begin{array}{c}17.30^{* * * *} \\
(1.86)\end{array}$ & $\begin{array}{c}12.23^{* * *} \\
(1.49)\end{array}$ & $\begin{array}{l}2.70^{* * * *} \\
(0.46)\end{array}$ & $\begin{array}{l}4.90^{* * * *} \\
(0.73)\end{array}$ \\
\hline Treatment group & $\begin{array}{c}0.65 \\
(1.30)\end{array}$ & $\begin{array}{l}-0.50 \\
(1.05)\end{array}$ & $\begin{array}{c}0.06 \\
(0.13)\end{array}$ & $\begin{array}{c}-7.99 \\
(18.81)\end{array}$ & $\begin{array}{c}-0.09 \\
(15.17)\end{array}$ & $\begin{array}{c}0.38 \\
(3.30)\end{array}$ & $\begin{array}{c}0.35 \\
(5.11)\end{array}$ \\
\hline Strong neighbor & $\begin{array}{c}2.08^{+} \\
(1.10)\end{array}$ & $\begin{array}{l}-0.46 \\
(0.83)\end{array}$ & $\begin{array}{l}-0.14 \\
(0.10)\end{array}$ & $\begin{array}{c}-2.70 \\
(16.70)\end{array}$ & $\begin{array}{c}-2.99 \\
(13.01)\end{array}$ & $\begin{array}{l}-1.34 \\
(2.96)\end{array}$ & $\begin{array}{l}-3.03 \\
(4.52)\end{array}$ \\
\hline $\begin{array}{l}\text { After initiative } x \\
\text { Treatment group }\end{array}$ & $\begin{array}{c}0.93 \\
(0.68)\end{array}$ & $\begin{array}{c}0.61 \\
(0.76)\end{array}$ & $\begin{array}{c}0.12 \\
(0.08)\end{array}$ & $\begin{array}{c}1.31 \\
(3.78)\end{array}$ & $\begin{array}{c}6.28^{*} \\
(3.12)\end{array}$ & $\begin{array}{l}1.72^{+} \\
(0.93)\end{array}$ & $\begin{array}{c}0.83 \\
(1.47)\end{array}$ \\
\hline Observations & 1323 & 1326 & 1324 & 1095 & 528 & 462 & 480 \\
\hline $\begin{array}{l}\text { Marginal } \mathrm{R}^{2} / \\
\text { Conditional } \mathrm{R}^{2}\end{array}$ & $\begin{array}{c}0.020 / \\
0.692\end{array}$ & $\begin{array}{c}0.073 / \\
0.515\end{array}$ & $\begin{array}{c}0.009 / \\
0.548\end{array}$ & $\begin{array}{c}0.006 / \\
0.951\end{array}$ & $0.013 / 0.943$ & $\begin{array}{c}0.018 / \\
0.898\end{array}$ & $0.020 / 0.892$ \\
\hline
\end{tabular}

Note. $+p<0.10, * p<0.05 * * p<0.01 * * * p<0.001$ 
Table 4. Regression models. Specification 2 with time as categorical variable, 2012 is reference year.

\begin{tabular}{|c|c|c|c|c|c|c|c|}
\hline & Model 2-1 & Model 2-2 & Model 2-3 & Model 2-4 & Model 2-5 & Model 2-6 & Model 2-7 \\
\hline & Mean USE & $\begin{array}{c}\% \text { of young } \\
\text { academics }\end{array}$ & $\begin{array}{c}\% \text { of } \\
\text { foreign } \\
\text { academics }\end{array}$ & $\begin{array}{l}\text { No. of publ. } \\
\text { in RISC } \\
\text { Core }\end{array}$ & $\begin{array}{l}\text { No. of publ. in } \\
\text { WoS }\end{array}$ & $\begin{array}{c}\text { No. of publ. } \\
\text { in WoS Q1 } \\
\text { journals }\end{array}$ & $\begin{array}{l}\text { No. of publ. in } \\
\text { WoS in } \\
\text { international } \\
\text { collaboration }\end{array}$ \\
\hline (Intercept) & $\begin{array}{c}62.79^{* * *} \\
(0.94)\end{array}$ & $\begin{array}{c}22.12^{* * *} \\
(0.77)\end{array}$ & $\begin{array}{l}0.49^{* * * *} \\
(0.09)\end{array}$ & $\begin{array}{l}78.99^{* * * *} \\
(13.47)\end{array}$ & $\begin{array}{l}30.01^{* *} \\
(10.15)\end{array}$ & $\begin{array}{l}5.14^{*} \\
(2.43)\end{array}$ & $\begin{array}{l}8.18^{*} \\
(3.60)\end{array}$ \\
\hline Year 2013 & $\begin{array}{l}3.18^{* * * *} \\
(0.53)\end{array}$ & $\begin{array}{l}-0.61 \\
(0.59)\end{array}$ & $\begin{array}{l}-0.04 \\
(0.07)\end{array}$ & $\begin{array}{c}2.11 \\
(2.77)\end{array}$ & $\begin{array}{c}2.04 \\
(2.28)\end{array}$ & $\begin{array}{c}0.66 \\
(0.73)\end{array}$ & $\begin{array}{c}1.83 \\
(1.14)\end{array}$ \\
\hline Year 2014 & $\begin{array}{l}-0.32 \\
(0.53)\end{array}$ & $\begin{array}{c}-2.60^{* * * *} \\
(0.59)\end{array}$ & $\begin{array}{l}-0.03 \\
(0.07)\end{array}$ & $\begin{array}{l}8.99^{* *} \\
(2.77)\end{array}$ & $\begin{array}{l}5.71^{*} \\
(2.28)\end{array}$ & $\begin{array}{l}1.81^{*} \\
(0.73)\end{array}$ & $\begin{array}{c}2.50^{*} \\
(1.14)\end{array}$ \\
\hline Year 2015 & $\begin{array}{c}0.56 \\
(0.53)\end{array}$ & $\begin{array}{c}-4.18^{* * * *} \\
(0.59)\end{array}$ & $\begin{array}{l}-0.03 \\
(0.07)\end{array}$ & $\begin{array}{c}17.43^{* * *} \\
(2.77)\end{array}$ & $\begin{array}{c}12.16^{* * * *} \\
(2.28)\end{array}$ & $\begin{array}{l}3.03^{* * * *} \\
(0.73)\end{array}$ & $\begin{array}{l}5.28^{* * * *} \\
(1.14)\end{array}$ \\
\hline Year 2016 & $\begin{array}{c}0.86 \\
(0.53)\end{array}$ & $\begin{array}{c}-6.14^{* * *} \\
(0.59)\end{array}$ & $\begin{array}{l}-0.03 \\
(0.07)\end{array}$ & $\begin{array}{c}28.66^{* * *} \\
(2.77)\end{array}$ & $\begin{array}{c}15.97^{* * * *} \\
(2.28)\end{array}$ & $\begin{array}{l}3.05^{* * * *} \\
(0.73)\end{array}$ & $\begin{array}{l}6.47^{* * * *} \\
(1.14)\end{array}$ \\
\hline Year 2017 & $\begin{array}{l}1.78^{* * * *} \\
(0.53)\end{array}$ & $\begin{array}{c}-7.16^{* * * *} \\
(0.59)\end{array}$ & $\begin{array}{l}-0.18^{* *} \\
(0.07)\end{array}$ & - & $\begin{array}{c}19.16^{* * *} \\
(2.28)\end{array}$ & $\begin{array}{l}4.22^{* * * *} \\
(0.73)\end{array}$ & $\begin{array}{l}9.02^{* * * *} \\
(1.14)\end{array}$ \\
\hline $\begin{array}{l}\text { Treatment } \\
\text { group }\end{array}$ & $\begin{array}{c}0.09 \\
(1.40)\end{array}$ & $\begin{array}{l}-0.27 \\
(1.20)\end{array}$ & $\begin{array}{c}0.06 \\
(0.14)\end{array}$ & $\begin{array}{c}-7.91 \\
(19.01)\end{array}$ & $\begin{array}{c}-1.82 \\
(15.34)\end{array}$ & $\begin{array}{c}0.41 \\
(3.38)\end{array}$ & $\begin{array}{c}0.04 \\
(5.23)\end{array}$ \\
\hline $\begin{array}{l}\text { Strong } \\
\text { neighbor }\end{array}$ & $\begin{array}{l}2.08^{+} \\
(1.10)\end{array}$ & $\begin{array}{l}-0.46 \\
(0.83)\end{array}$ & $\begin{array}{l}-0.14 \\
(0.10)\end{array}$ & $\begin{array}{c}-2.70 \\
(16.70)\end{array}$ & $\begin{array}{c}-2.99 \\
(13.01)\end{array}$ & $\begin{array}{l}-1.34 \\
(2.96)\end{array}$ & $\begin{array}{l}-3.03 \\
(4.52)\end{array}$ \\
\hline $\begin{array}{l}\text { Year } 2013 \mathrm{x} \\
\text { Treatment } \\
\text { group }\end{array}$ & $\begin{array}{c}1.13 \\
(1.07)\end{array}$ & $\begin{array}{l}-0.46 \\
(1.19)\end{array}$ & $\begin{array}{l}-0.00 \\
(0.14)\end{array}$ & $\begin{array}{l}-0.17 \\
(5.63)\end{array}$ & $\begin{array}{c}3.46 \\
(4.78)\end{array}$ & $\begin{array}{l}-0.08 \\
(1.47)\end{array}$ & $\begin{array}{c}0.62 \\
(2.27)\end{array}$ \\
\hline $\begin{array}{l}\text { Year } 2014 \text { x } \\
\text { Treatment } \\
\text { group }\end{array}$ & $\begin{array}{l}1.81^{+} \\
(1.07)\end{array}$ & $\begin{array}{c}0.00 \\
(1.19)\end{array}$ & $\begin{array}{c}0.09 \\
(0.14)\end{array}$ & $\begin{array}{c}0.71 \\
(5.63)\end{array}$ & $\begin{array}{c}5.04 \\
(4.78)\end{array}$ & $\begin{array}{l}-0.44 \\
(1.47)\end{array}$ & $\begin{array}{c}0.80 \\
(2.27)\end{array}$ \\
\hline $\begin{array}{l}\text { Year } 2015 \text { x } \\
\text { Treatment } \\
\text { group }\end{array}$ & $\begin{array}{c}1.54 \\
(1.07)\end{array}$ & $\begin{array}{l}-0.03 \\
(1.19)\end{array}$ & $\begin{array}{c}0.13 \\
(0.14)\end{array}$ & $\begin{array}{l}-0.96 \\
(5.63)\end{array}$ & $\begin{array}{c}6.74 \\
(4.78)\end{array}$ & $\begin{array}{c}1.54 \\
(1.47)\end{array}$ & $\begin{array}{c}0.82 \\
(2.27)\end{array}$ \\
\hline $\begin{array}{l}\text { Year } 2016 \text { x } \\
\text { Treatment } \\
\text { group }\end{array}$ & $\begin{array}{c}1.14 \\
(1.07)\end{array}$ & $\begin{array}{c}1.06 \\
(1.19)\end{array}$ & $\begin{array}{l}-0.01 \\
(0.14)\end{array}$ & $\begin{array}{c}3.93 \\
(5.63)\end{array}$ & $\begin{array}{c}8.03^{+} \\
(4.78)\end{array}$ & $\begin{array}{c}3.32^{*} \\
(1.47)\end{array}$ & $\begin{array}{c}1.73 \\
(2.27)\end{array}$ \\
\hline $\begin{array}{l}\text { Year } 2017 \text { x } \\
\text { Treatment } \\
\text { group }\end{array}$ & $\begin{array}{c}1.47 \\
(1.08)\end{array}$ & $\begin{array}{c}0.47 \\
(1.19)\end{array}$ & $\begin{array}{c}0.28^{*} \\
(0.14)\end{array}$ & & $\begin{array}{l}12.24^{*} \\
(4.78)\end{array}$ & $\begin{array}{c}2.30 \\
(1.47)\end{array}$ & $\begin{array}{c}1.18 \\
(2.27)\end{array}$ \\
\hline Observations & 1323 & 1326 & 1324 & 1095 & 528 & 462 & 480 \\
\hline $\begin{array}{l}\text { Marginal R2 / } \\
\text { Conditional } \mathrm{R}^{2}\end{array}$ & $\begin{array}{c}0.037 / \\
0.711\end{array}$ & $\begin{array}{c}0.104 / \\
0.550\end{array}$ & $\begin{array}{c}0.012 \text { / } \\
0.550\end{array}$ & $\begin{array}{c}0.009 / \\
0.955\end{array}$ & $0.020 / 0.949$ & $0.025 / 0.904$ & $0.030 / 0.902$ \\
\hline
\end{tabular}

Note. $+p<0.10, * p<0.05 * * p<0.01 \quad * * * p<0.001$ 
$\mathrm{N}$ of publications with RUEI universities

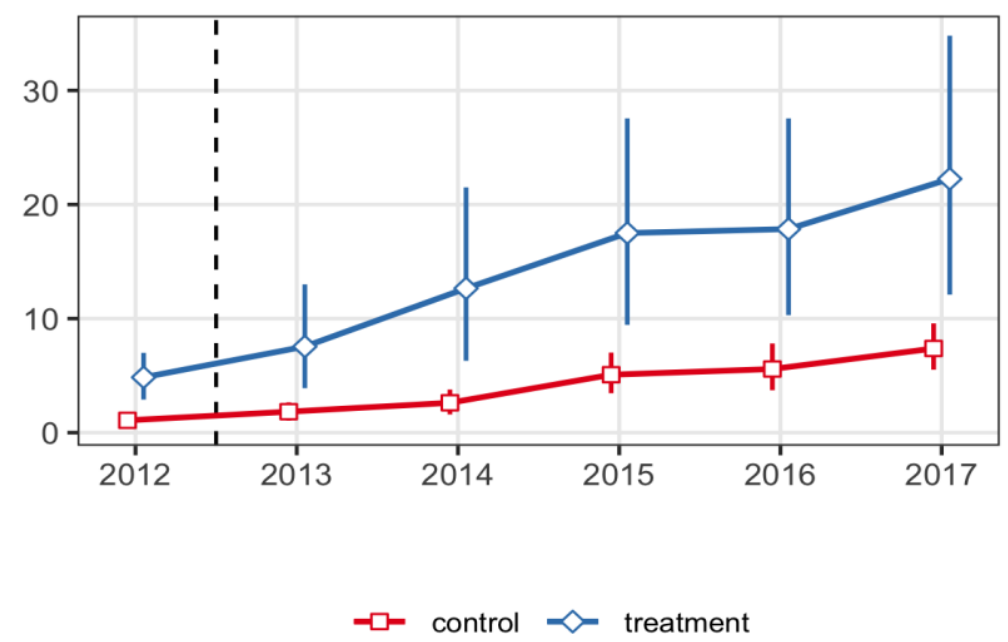

Figure 7. Means and $95 \%$ confidence intervals for number of publications in collaboration with RUEI universities indexed in the WoS

Table 5. Regression models for number of publications indexed in the WoS, in collaboration with RUEI universities.

\begin{tabular}{|c|c|c|}
\hline & $\begin{array}{c}\text { Model 1-8 } \\
\text { No. of publications in collaboration } \\
\text { with RUEI universities }\end{array}$ & $\begin{array}{c}\text { Model 2-8 } \\
\text { No. of publications in collaboration with } \\
\text { RUEI universities }\end{array}$ \\
\hline (Intercept) & $\begin{array}{c}1.10 \\
(2.03)\end{array}$ & $\begin{array}{c}0.74 \\
(2.11)\end{array}$ \\
\hline After initiative & $\begin{array}{l}3.44^{* * * *} \\
(0.72)\end{array}$ & \\
\hline Treatment group & $\begin{array}{l}4.71^{+} \\
(2.73)\end{array}$ & $\begin{array}{l}3.72 \\
(2.92)\end{array}$ \\
\hline Strong neighbor & $\begin{array}{l}0.46 \\
(2.44)\end{array}$ & $\begin{array}{l}0.46 \\
(2.44)\end{array}$ \\
\hline After initiative $\mathrm{x}$ Treatment group & $\begin{array}{l}7.92^{* * * *} \\
(1.39)\end{array}$ & \\
\hline Year 2013 & & $\begin{array}{c}0.72 \\
(1.12)\end{array}$ \\
\hline Year 2014 & & $\begin{array}{l}1.43 \\
(1.12)\end{array}$ \\
\hline Year 2015 & & $\begin{array}{l}3.72^{* * *} \\
(1.12)\end{array}$ \\
\hline Year 2016 & & $\begin{array}{l}4.20^{* * * *} \\
(1.12)\end{array}$ \\
\hline Year 2017 & & $\begin{array}{l}5.87^{* * * *} \\
(1.12)\end{array}$ \\
\hline Year 2013 x Treatment group & & $\begin{array}{l}1.98 \\
(2.16)\end{array}$ \\
\hline Year 2014 x Treatment group & & $\begin{array}{l}6.37^{* *} \\
(2.16)\end{array}$ \\
\hline Year 2015 x Treatment group & & $\begin{array}{l}8.93^{* * * *} \\
(2.16)\end{array}$ \\
\hline Year 2016 x Treatment group & & $\begin{array}{l}8.80^{* * *} \\
(2.16)\end{array}$ \\
\hline Year 2017 x Treatment group & & $11.53^{* * *}(2.16)$ \\
\hline $\begin{array}{l}\text { Observations } \\
\text { Marginal } R^{2} \text { / Conditional } R^{2}\end{array}$ & $\begin{array}{c}444 \\
0.196 / 0.754\end{array}$ & $\begin{array}{c}444 \\
0.218 / 0.778\end{array}$ \\
\hline
\end{tabular}




\section{Discussion and Conclusions}

Excellence initiatives do not exist in a vacuum and may potentially affect the entire national higher education systems. Concern about the consequences of such targeted programs has been around for a long time. While some experts underline the importance of such programs for increasing overall competitiveness and development of the systems, others warn to beware of potential "vacuum cleaner" effect of these programs when supported universities use their more privileged position to extract human resources from weaker institutions. However, any possible positive and negative externalities are usually not yet taken into account in the design of such government interventions. In many countries, a significant gap between universities inside and outside excellence initiatives is visible, but little is still known what exactly happens to those outside.

Our analysis suggests the evidence for vertical differentiation has increased in Russia since the implementation of the program. Differences in the quality of faculty human capital and research output are increasing. Concurrently the gap in the quality of students did not increase. Universities in both groups - within and outside the excellence initiative - increased their research output having aimed to extend their existence beyond mere teaching logic and improve their standing as knowledge producers. We believe that such a profound change in the ambitions and goals of many universities in the system is associated with those values that we transmitted to Russian university community via the very design of the excellence initiative with research now considered as a key element of university success and prosperity.

Such a comparison, however, does not allow us to make any statements about redistribution of resources and impact on output at the local level. So we go further by looking at potential spillover effects from participating universities on their geographical neighbors. And indeed we find something that suggests to us the idea that the financial redistribution effect may matter, more subtle effects of local communication between universities are indeed playing an important role. There are many regions in Russia with universities included in the initiative and also without such universities. That has allowed us to see how a selected university affects other universities in its home region: i.e., whether or not it forces the redistribution of human capital toward. There is no regional spillover effect on the staff rejuvenation share, but the share of young academics in non-RUEI universities fell during this period. The cause of this phenomenon is that the academic profession is in general not attractive for young people and only universities from the excellence initiative can attract and keep young faculty (Finkelstein et al., 2015). As for foreign faculty, we do not see the overall effect. However, we see a statistically significant effect in 2017 and at the present moment it is difficult to say how persistent it would be. We also did not find any effect on student quality. Thus, we can argue that despite the presence of a difference in human capital between RUEI 
universities and non-RUEI universities, we do not see any special effect in the redistribution of human capital at the local level due to the proximity to RUEI universities. We discovered an important effect associated with a statistically significant increase in collaboration in publications between RUEI universities and neighboring institutions. We found an interesting phenomenon concerning research output: the effect of the proximity to a RUEI university appears only at the international level, not at the national level. At the same time, there is no influence on international collaboration in publications. There is a positive overall effect on the number of publications in journals with higher quality and international visibility. Thus, we found an effect related to research activities and particularly in those indicators which are key indicators for universities within the excellence initiative and about which RUEI universities should report to the Ministry. This effect has only recently appeared, which may be due to the fact that it takes a long time to develop an idea and take it through to an international journal article. The main channel for increasing the international visibility of local universities is associated with collaboration with RUEI universities. In general, it can be argued that the RUEI becomes a driver for the regional academic market with RUEI universities playing a role of learning peers for their weaker neighbors.

Based on the results of this study on the external effects of the RUEI, several conclusions can be drawn. First, to the best of our knowledge, these results are one of the first empirical demonstrations of the impact of an excellence initiative on parts of the academic system that are not a direct part of that initiative. Our results demonstrate that the RUEI can influence neighboring universities that are not part of this program, i.e. not directly supported by the initiative. It reinforces the concerns of those researchers who raise questions about the impact of the initiative on the rest of the academic system (Gaehtgens, 2015; Kehm, 2013; Liu et al., 2016). This conclusion is important for policy, because it is empirical evidence suggesting that the potential impact of an excellence initiative on the rest of the academic system should be considered when developing its design and implementation. There are several reasons that may explain a lack of a significant impact on human capital redistribution: first, it may be the case that increased RUEI output is due to intensification of use of existing resources (through a strict implementation of publish-or-perish principle), second, not much time has passed since the implementation of RUEI and the reshaping of human capital mobility has not yet manifested itself.

Thus, some spillover effects do exist. Universities participating in the RUEI have created their own development strategies and are progressing well in accordance with those strategies. This development positively affects their neighboring environment. The observed increase in the number of articles in international journals published in collaboration with RUEI universities suggests that participants in the initiative have a positive impact on the neighboring environment. This impact enriches the academic environment, involving academics from neighboring universities in joint 
research. The results of this study, taken together with those of previous studies that evaluated the direct effect of the RUEI on participating universities (Matveeva et al., 2019; Poldin et al., 2017; Turko et al., 2016, Matveeva and Ferligoj, 2020), provide grounds for evaluating this initiative mostly as positive in its results, at least in the short run.

Based on evidence from the RUEI, one can initially conclude that such initiatives can be useful, not only for direct participants, but also for other parts of the academic system that do not receive direct support from the initiative. Of course, not all aspects of the functioning of universities that could be affected by the RUEI have yet been analyzed. However, the data obtained to date indicate a positive influence, and there is no empirical evidence for stating any detrimental effect of the RUEI on the academic system as a whole.

Our study has several limitations. The set of indicators that we can use is limited. While it allows to measure the changes in research output and quality of human capital, it does not allow to access the impact of the program beyond these dimensions. Then, not much time has passed since the start of the RUEI and it is still too early to estimate the long-term effects of this program. Recently, a new program - Excellence Initiative for Strategic Leadership - has been announced by the Ministry. While the details of the program design are not available yet, it has been announced that it would assume two tiers. Both leading national universities and some regional-level universities will be selected on the competitive basis and will get differentiated support. Such an approach is in line with our general conclusion on the significant role of regional university drivers for the national higher education system. 


\section{References}

Astebro, T., Bazzazian, N. (2011) 'Universities, Entrepreneurship and Local Economic Development'. In Fritsch, M. (ed.) Handbook of Research on Entrepreneurship and Regional Development: National and Regional Perspectives, pp. 252-333. Edward Elgar Publishing: Cheltenham.

Altbach, P. (2003) 'The Costs and Benefits of World-class Universities', International Higher Education, 33: 5-10.

Altbach, P. (2011) Leadership for World-class Universities: Challenges for Developing Countries. London: Routledge.

Altbach, P. Salmi, J. (2011) The Road to Academic Excellence: Emerging Research Universities in Developing and Transition countries. Washington, DC: The World Bank.

Altbach, P., Reisberg, L., de Wit, H. (2017) Responding to Massification: Differentiation in Postsecondary Education Worldwide. Rotterdam: Sense Publishers.

Bates, D., Mächler, M., Bolker, B., Walker, S. (2015) 'Fitting Linear Mixed-Effects Models Using Ime4', Journal of Statistical Software, 67/1: 1-48. https://doi.org/10.18637/jss.v067.i01

Benito, M., Gil, P., Romera, R. (2019) 'Funding, is it Key for Standing Out in the University Rankings?' Scientometrics, 121: 771-792. https://doi.org/10.1007/s11192-019-03202-z

Bhardwa, S. (2017) 'Why do Students Go to University and How Do They Choose Which One', Times Higher Education. (downloaded on 5 February 2020 from https://www.timeshighereducation.com/student/news/why-do-students-go-universityandhow-do-they-choose-which-one.)

Brown, D.G. (1967) The Mobile Professors. Washington: American Council on Education.

Clark, B.R. (1996) 'Substantive Growth and Innovative Organization: New Categories for Higher Education Research', Higher Education, 32/4: 417-430. https://doi.org/10.1007/BF00133256

Clark, B.R. (2002) 'University Transformation: Primary Pathways to University Autonomy and Achievement'. In Brint, S. (ed.) The Future of the City of Intellect: The Changing American University, pp. 322-342. Stanford University Press: Stanford.

Cremonini, L., Benneworth, P., Dauncey, H., Westerheijden, D. (2013) 'Reconciling Republican 'Egalite' and Global Excellence Values in French Higher Education'. In Shin, J., Kehm, B. (eds.) Institutionalization of World-class University in Global Competition, pp. 99-123. Springer: Dordrecht. 
Cook, P., Frank, R. (1993) 'The Growing Concentration of Top Students at Elite Schools', in Clotfelter, C., Rothschild, M. (eds.) Studies and Demand in Higher Education, pp.121-144. University of Chicago Press: Chicago.

Cordes, S.A. (2018) 'In Pursuit of the Common Good: The Spillover Effects of Charter Schools on Public School Students in New York City', Education Finance and Policy, 13/4: 484512. https://doi.org/10.1162/edfp_a_00240

Croucher, G., Woelert, P. (2016) 'Institutional Isomorphism and the Creation of the Unified National System of Higher Education in Australia: an Empirical Analysis', Higher Education, 71/4: 439- 453. https://doi.org/10.1007/s10734-015-9914-6

Cuntz, A. (2016) 'Do Public R\&D Funds Affect the Location Choices of Elite Scientists in Europe?' Research Evaluation, 25/4: 383-395. https://doi.org/10.1093/reseval/rvw011

Guskov, A., Kosyakov, D., Selivanova, I. (2017) 'Strategies to improve publication activities of the universities participating in Project 5-100', Nauchnye I Tekhnicheskie Biblioteki/Scientific and Technical Libraries. 1(12):5-18. In Russian.

DiMaggio, P.J., Powell, W.W. (1983) 'The Iron Cage Revisited: Institutional Isomorphism and Collective Rationality in Organizational Fields', American Sociological Review, 48/2: 147160. https://doi.org/10.1007/s10734-015-9914-6

Drucker, J., Goldstein, H. (2007) 'Assessing the Regional Economic Development Impacts of Universities: A Review of Current Approaches', International Regional Science Review, 30/1: 20- 46. https://doi.org/10.1177/0160017606296731

Edmark, K. (2019) 'Location Choices of Swedish Independent Schools', The Annals of Regional Science, 63/1: 219-239. https://doi.org/10.1007/s00168-019-00933-y

Epple, D., Romano, R.E. (1998) 'Competition Between Private and Public Schools, Vouchers, and Peer-group effects', American Economic Review, 88/1: 33-62.

Ferreyra, M.M., Kosenok, G. (2018) 'Charter School Entry and School Choice: The Case of Washington, DC', Journal of Public Economics, 159: 160-182. https://doi.org/10.1016/i.jpubeco.2017.12.008

Finkelstein, M., Iglesias K., Panova A., Yudkevich M. (2015) 'Future Prospects for Young Faculty Across the Academic World: A Global Comparison and Assessment'. In Yudkevich, M., Altbach, P.G., Rumbley, L. E. (eds.) Young Faculty in the 21st Century: International Perspectives, pp. 321-350. State University of New York Press: NY, Albany.

Fu, Y.C., Baker, D.P., Zhang, L. (2018) 'Engineering a World Class University? The Impact of Taiwan's World Class University Project on Scientific Productivity', Higher Education Policy: 1-16, https://doi.org/10.1057/s41307-018-0110-z 
Gaehtgens, C. (2015) 'Does Size Matter?-The Example of the "Excellence Initiative" and its Impact on Smaller Universities in Germany'. In Pritchard, R., Klumpp, M., Teichler, U. (eds.) Diversity and Excellence in Higher Education, pp. 19-30. Sense Publishers: Rotterdam.

Guskov, A.E., Kosyakov, D.V., Selivanova, I.V. (2018) 'Boosting Research Productivity in Top Russian Universities: the Circumstances of Breakthrough', Scientometrics, 117/2: 10531080. https://doi.org/10.1007/s11192-018-2890-8

Hallonsten, O., Holmberg, D. (2013) 'Analyzing Structural Stratification in the Swedish Higher Education System: Data Contextualization with Policy-history Analysis', Journal of the American Society for Information Science and Technology, 64/3: 574-586. https://doi.org/10.1002/asi.22773

Hou, A.Y.C., Ince, M., Chiang, C.L. (2012) 'A Reassessment of Asian pacific Excellence Programs in Higher Education: the Taiwan Experience', Scientometrics, 92/1: 23-42. https://doi.org/10.1007/s11192-012-0727-4

Kashnitsky I., Mkrtchyan, N., Leshukov. O. (2016) 'Mezhregional'naya Migratsiya Molodezhi v Rossii: Kompleksnyy Analiz Demograficheskoy Statistiki' ['Interregional Migration of Youths in Russia: A Comprehensive Analysis of Demographic Statistics'], Voprosy Obrazovaniya / Educational Studies Moscow, 3: 169-203. https://doi.org/10.17323/1814-9545-2016-3-169-203

Kehm, B. (2013) 'To Be or not to Be? The Impacts of the Excellence Initiative on the German System of Higher Education'. In Shin, J., Kehm, B. (eds.) Institutionalization of world-class university in global competition, pp. 81-97. Springer: Dordrecht.

Koenig, J., Brenner, T., Buenstorf, G. (2017) 'Regional Effects of University Funding: Excellence at the Cost of Regional Disparity?', Review of Regional Research, 37/2: 111-133. https://doi.org/10.1007/s10037-017-0117-8

Kosyakov, D., Guskov, A. (2019) 'Impact of national science policy on academic migration and research productivity in Russia', Procedia Computer Science. 146:60-71.

Kuskova, V., Yudkevich, M. (2016) 'International Academic Recruitment in a Turbulent Environment: The Case of the Higher School of Economics in Russia'. In Altbach, P., Yudkevich, M., Rumbley, L.E. (eds.) International Faculty in Higher Education, pp. 206229. Routledge: New York.

Liu, N.C., Cheng, Y., Wang, Q. (2016) 'Matching Visibility and Performance: A Standing Challenge for World-Class Universities'. In Liu, N.C, Cheng, Y., Wang, Q. (eds.) Matching Visibility and Performance, pp. 1-11. Sense Publishers: Rotterdam. 
McGee, G.W., Ford, R.C. (1987) 'Faculty Research Productivity and Intention to Change Positions', The Review of Higher Education, 11/1: 1-16. https://doi.org/10.1353/rhe.1987.0005

Matveeva, N., Ferligoj, A. (2020) 'Scientific Collaboration in Russian Universities before and after the Excellence Initiative Project 5-100', Scientometrics. https://doi.org/10.1007/s11192-020-03602-6

Matveeva, N., Sterligov, I., Yudkevich, M. (2019) 'The Russian University Excellence Initiative: Is It Really Excellence that Is Promoted?', Higher School of Economics Research Paper No. WP BRP, 49. (downloaded on 5 February 2020 from https://wp.hse.ru/data/2019/05/20/1509096657/49EDU2018.pdf)

Menter, M., Lehmann, E.E., Klarl, T. (2018) 'In Search of Excellence: a Case Study of the First Excellence Initiative of Germany', Journal of Business Economics, 88/9: 1105-1132. https://doi.org/10.1007/s11573-018-0909-5

Ming, J.K.S. (2010) 'Institutional Factors Influencing Students' College Choice Decision in Malaysia: A Conceptual Framework', International Journal of Business and Social Science, 1/3: 53-58.

Ministry of Education and Science of Russia. (2020) 'Monitoring of the Effectiveness of Educational Institutions'. [online] Available at: <http://indicators.miccedu.ru/monitoring/?m=vpo> [Accessed 26 June 2020].

Moed, H.F. (2017) 'A Critical Comparative Analysis of five World University Rankings'. Scientometrics, 110: 967-990. https://doi.org/10.1007/s11192-016-2212-y

Moskaleva, O., Pislyakov, V., Sterligov, I., Akoev, M., Shabanova, S. (2018) 'Russian Index of Science Citation: Overview and Review', Scientometrics, 116/1: 449-462. https://doi.org/10.1007/s11192-018-2758-y

Möller, T., Schmidt, M., Hornbostel, S. (2016) 'Assessing the Effects of the German Excellence Initiative with Bibliometric Methods', Scientometrics, 109/3: 2217-2239. https://doi.org/10.1007/s11192-016-2090-3

Poldin, O., Matveeva, N., Sterligov, I., Yudkevich, M. (2017) 'Publikatsionnaya Aktivnost' Vuzov: Effekt Proekta «5-100»' ['Publication Activities of Russian Universities: The Effects of Project 5-100'], Voprosy obrazovaniya / Educational Studies Moscow, 2: 10-35. (in Russian). https://doi.org/10.17323/1814-9545-2017-2-10-35

Powell, J.J., Fernandez, F., Crist, J.T., Dusdal, J., Zhang, L., Baker, D.P. (2017) 'Introduction: The Worldwide Triumph of the Research University and Globalizing science'. In Powell, J.J., Baker, D.P., Fernandez, F. (eds.) The Century of Science: The global Triumph of the Research 
University, pp. 1-36. Emerald Publishing Limited: Bingley, UK. https://doi.org/10.1108/S1479-367920170000033003

Salmi, J. (2016) 'Excellence Strategies and the Creation of World-class Universities’. In Liu, N.C., Cheng, Y., Wang, Q. (eds.) Matching Visibility and Performance, pp. 13-48. Sense Publishers: Rotterdam.

Seeber, M., Lepori, B., Agasisti, T., Tijssen, R., Montanari, C. Catalano, G. (2012) 'Relational Arenas in a Regional Higher Education System: Insights from an Empirical Analysis', Research Evaluation, 21/4: 291-305. https://doi.org/10.1093/reseval/rvs023

Sharma, Y. (2017) 'World-class Universities Policy Fuels Talent Poaching', University World News, March 16, Issue No: 451. (downloaded on 5 February 2020 from http://www.universityworldnews.com/article.php?story=20170316143426976)

Shin, J.C., Jang, Y.S. (2013) 'World-class University in Korea: Proactive Government, Responsive University, and Procrastinating Academics'. In Shin, J., Kehm B. (eds.) Institutionalization of World-class University in Global Competition, pp. 147-163. Springer: Dordrecht.

Tayeb, 0. (2016) 'Roadmap to Become a World-Class University'. In: Tayeb, O., Zahed, A., Ritzen, J. (eds.) Becoming a World-Class University. Springer: Cham.

Teichler, U. (2008) 'Exzellenz und Differenzierung: Auf der Suche nach einer neuen Systemlogik', $i F Q, 13$

Top Universities. 2020. QS World University Rankings 2019: Russia. [online] Available at: <https://www.topuniversities.com/university-rankings-articles/world-universityrankings/qs-world-university-rankings-2019-russia> [Accessed 26 June 2020].

Turko, T., Bakhturin, G., Bagan, V., Poloskov, S., Gudym, D. (2016). Influence of the Program “5top 100" on the Publication Activity of Russian Universities, Scientometrics, 109/2: 769782. https://doi.org/10.1007/s11192-016-2060-9

Wondratschek, V., Edmark, K., Frölich, M. (2013) 'The Short-and Long-term Effects of School Choice on Student Outcomes - Evidence from a School Choice Reform in Sweden', Annals of Economics and Statistics/ANNALES D'ÉCONOMIE ET DE STATISTIQUE, 111: 71101. https://doi.org/10.2307/23646327

Yonezawa, A., Shimmi, Y. (2016) 'Transformation of University Governance through Internationalization'. In Liu, N.C, Cheng, Y., Wang, Q. (eds.) Matching Visibility and Performance, pp. 103-118. Sense Publishers: Rotterdam.

Zhou, Y., Volkwein, J.F. (2004) 'Examining the Influences on Faculty Departure Intentions: A Comparison of Tenured versus Nontenured Faculty at Research Universities using 
NSOPF-99', Research in Higher Education, 45/2: 139-176. https://doi.org/10.1023/B:RIHE.0000015693.38603.4c

Zong, X., Zhang, W. (2019) 'Establishing World-class Universities in China: Deploying a Quasi Experimental Design to Evaluate the Net Effects of Project 985', Studies in Higher Education, 44/3: 417-431. https://doi.org/10.1080/03075079.2017.1368475 


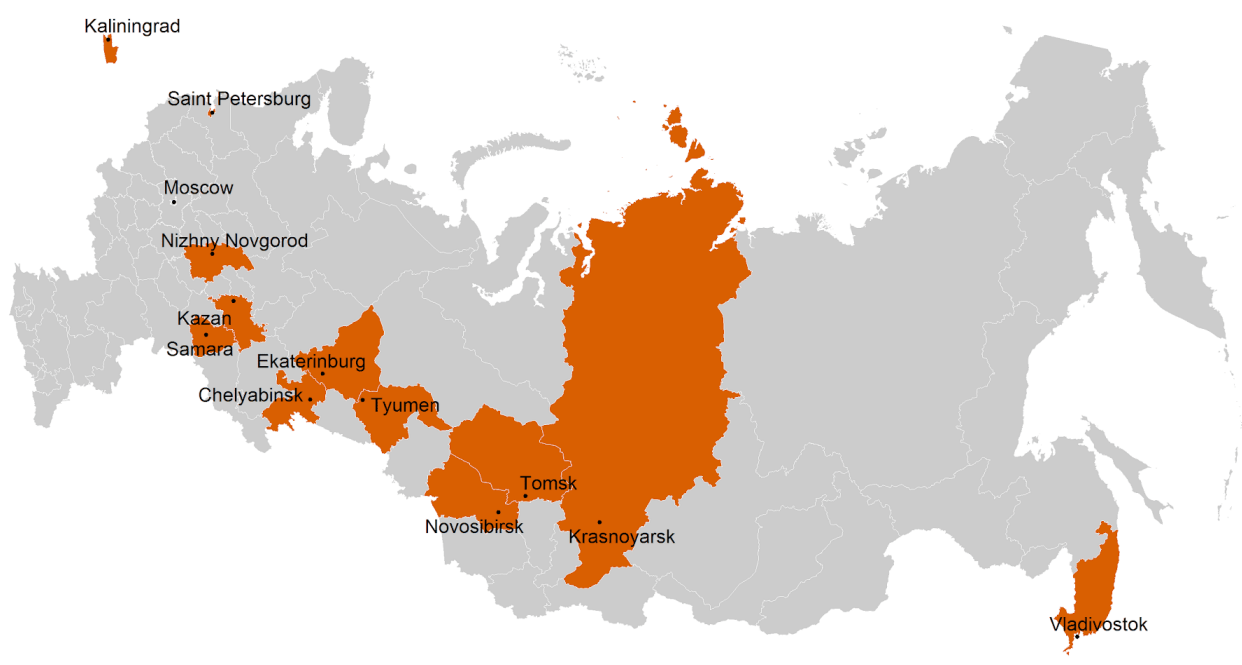

Figure 1. Distribution of regions and cities with universities from the Russian University Excellence Initiative across Russia.

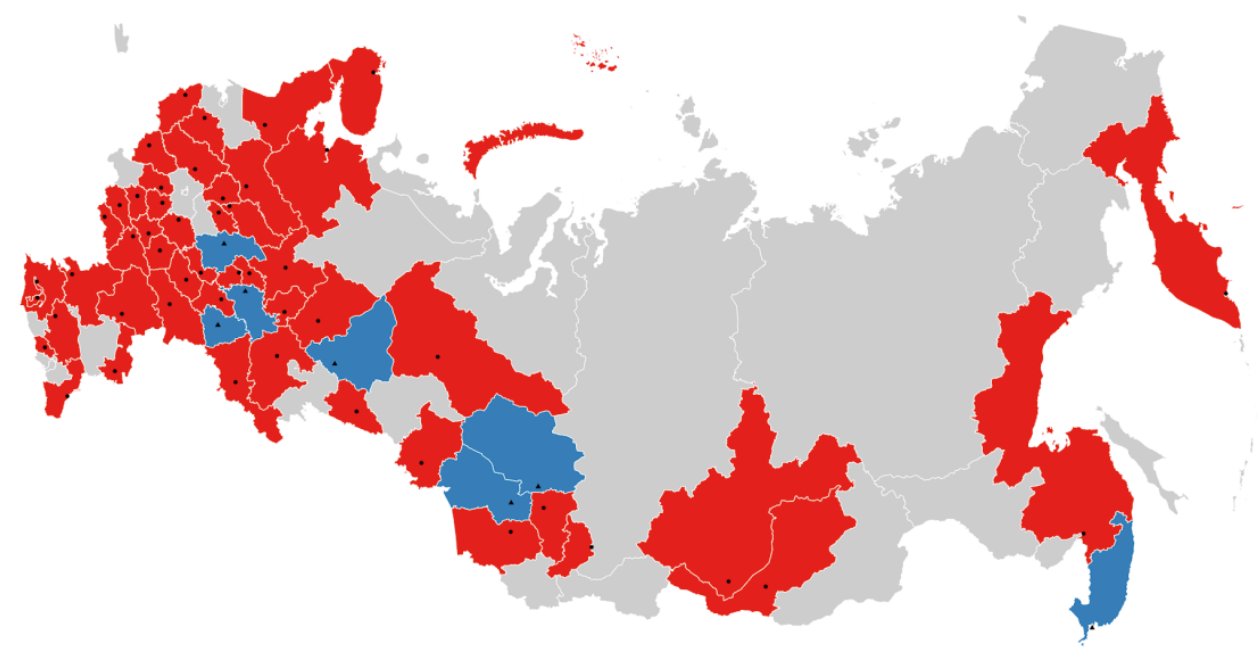

Figure 2. Distribution of regions and cities with universities from the treatment (blue) and control (red) groups. 